\title{
A FOLLOW-UP STUDY OF DYSMATURE INFANTS*
}

\author{
BY \\ G. ENGLESON, G. ROOTH and M. TÖRNBLOM \\ From Aid of Crippled Children Laboratory, Departments of Obstetrics and Gynaecology. \\ Paediatrics, and Educational Psychology, University of Lund, Sweden
}

(RECEIVED FOR PUBLICATION SEPTEMBER 17, 1962)

Very little is known about the subsequent fate of infants who are dysmature at birth. The series of infants studied by Sjöstedt, Engleson and Rooth (1958) offers an opportunity for a follow-up study which would disclose whether dysmaturity is only a term of significance in the neonatal period or also has relevance to the subsequent fate of the infant.

As was shown in 1958 the dysmature infants, who were classified according to Clifford's Stages 0 to 3 (Sjöstedt et al., 1958), differed from normal newborn infants in a number of parameters studied. Thus, in the cord blood, the mean oxygen saturation was lower in dysmature infants than in the controls, whereas haemoglobin concentration, plasma pentoses, protein-bound hexoses, bilirubin and nonprotein nitrogen was higher in the dysmature than in the control groups. Also the mean weight was lower in the dysmature group, and they showed an increased frequency of albuminuria and glycosuria during the first days of life. The differences were interpreted as signs of placental insufficiency, although there was no correlation between the stage of dysmaturity and the absolute or relative size of the placenta.

As the number of cases of dysmaturity Stage 2 was sufficiently large for a statistical evaluation of the results these children were selected for a follow-up study and controls were matched with them.

\section{Material and Methods}

The mothers of the initial 41 cases of Stage 2 dysmatures were asked by letter whether they would participate in the follow-up study. The same applied to the four cases of Stage 3. Thirty-one Stage 2, and three Stage 3, agreed to participate.

Controls were chosen from infants of dysmaturity Stage 0 , of the same sex as the probands, whose mothers were of the same parity and approximately the same agegroups, who had been delivered normally and in whom there was no obvious disease in either infant or mother, which might have a bearing on the subject of this paper. If the mother of this case did not come to our study,

- This study was supported by a grant from the Association for the Aid of Crippled Children, New York. the second case born after the proband and fitting the same conditions was selected.

The total number of Stage 1 infants was large enough to necessitate a random selection of these cases. The first Stage 1 infant born on the first or the fifteenth of the month was admitted to the study.

Of all those asked, the following number agreed to take part in the study: 34 of Stage 2 and $3(75 \%), 27$ of Stage $1(75 \%)$ and $19(58 \%)$ of controls in Stage 0. It was considered likely that the sampling would be representative of the Stage 2 and 1 infants, and that the pure random selection used for Stage 0 would prevent undue bias. The infants were born in 1956 and 1957 being at the time of study between 4 and 5 years of age. The three Stage 3 cases turned out to fall within the variation in Stage 2 and are therefore pooled with Stage 2. The sex distribution is shown in Table 1.

TABLE 1

SEX DISTRIBUTION OF THE MATERIAL

\begin{tabular}{cccc}
\hline Stage & Boys & Girls & All \\
\cline { 4 - 5 } \cline { 4 - 5 } & 13 & 6 & 19 \\
1 & 11 & 16 & 27 \\
2 & 23 & 11 & 34 \\
\hline
\end{tabular}

The socio-economic status of the population studied is homogeneous. No division into social groups has therefore been made.

Findings at Birth. In order to study the influence of the delivery on the initial dysmaturity staging and the subsequent clinical findings the case records were analysed for age and parity of the mother (Table 2), gestation time and time of delivery. Also other abnormalities were noted.

According to the selection used the Stage 2 and Stage 0 mothers should be of the same parity and within the same age-group.

TABLE 2

\begin{tabular}{|c|c|c|c|}
\hline Stage & $\begin{array}{c}\text { Mean Maternal Age } \\
\text { (years) }\end{array}$ & Primiparac & Multiparae \\
\hline $\begin{array}{l}0 \\
1 \\
2\end{array}$ & $\begin{array}{l}28 \cdot 7 \\
28 \cdot 0 \\
29 \cdot 8\end{array}$ & $\begin{array}{l}61 \\
44 \\
50\end{array}$ & $\begin{array}{l}39 \\
56 \\
50\end{array}$ \\
\hline
\end{tabular}


It will be seen that in spite of the selection used, Stage 2 mothers are $1 \cdot 1$ years older than the controls. This difference is almost significant $(t=2 \cdot 1 ; p<0.05)$. The difference between the maternal age in Stages 2 and 1 , where no influence of selection was present, is highly significant $(\mathrm{t}=3.8 ; \mathrm{p}<0.001)$.

There are proportionately more primiparae in the control series. It is possible that mothers whose firstborns were asked to participate were more likely to come.

Table 3 shows some data from the delivery records, which are not affected by the selection of the material for the follow-up study. The average gestation time in Stage 2 is significantly longer than in Stage $0(t=2 \cdot 6$; $\mathrm{p}<\mathbf{0 . 0 1})$ in agreement with the findings of Sjöstedt $e t$ al. (1958), and it will be seen that as expected Stage 1 holds an intermediate position between Stages 0 and 2 .

In spite of the high percentage of primiparae in Stage 0 the delivery time is shorter than in the other stages. The difference between Stage 2 and 0 is almost significant $(\mathrm{t}=2.0 ; \mathrm{p}<0.05)$.

Of the control mothers one had signs of pre-eclampsia, and in one case occasional slowing of the foetal heart sounds had been observed.

Of the Stage 1 infants, one was delivered by forceps and one was a breech presentation.

In 22 of the Stage 2 cases no clue was offered as to why the infants were dysmature. Abnormal findings were obtained either from the maternal case history or the delivery records in 12 cases.

The case history and the physical examination were carried out by one physician, who did not know the dysmaturity stage of the infants. The results were recorded for each infant on a protocol in which the numbers of selected variables were set out to which answers were scored according to four Grades 0-3. If the answers were unknown, this was recorded in a special Grade X (Table 4).

The variables $5,6,7$ and 8 relating to sitting, walking, talking and becoming dry were scored according to time of development (Table 5). Thus, a score of $0,1.2$ or 3 was awarded as follows: for sitting, within $6,7,8$ or over 8 months; for walking and talking, within 12, 13-15, 16-18 or over 18 months; for becoming dry, within 2, $2 \frac{1}{2}, 3$ and over 3 years.

Hospitalization (variable 10) was scored either Yes (0) or No (1).

It was originally planned to include an electroencephalogram on each child, but for technical reasons this was not possible.

Intelligence Tests. All the infants were tested on the second visit according to the Terman-Merrill and the Goodenough scales by the same investigator who was also ignorant of the dysmaturity stage of the infant. For each test the actual score obtained is recorded.

Height and Weight. As the age distribution of the groups differed somewhat it was necessary to correct height and weight for age. This was done by comparing the actual height and weight of the infant with the normal standards for a Swedish population of Karlberg and Perman (1959). Both height and weight are expressed
TABLE 3

\begin{tabular}{ccccc}
\hline Stage & $\begin{array}{c}\text { Mean } \\
\text { Gestation Time } \\
\text { (wks) }\end{array}$ & $\begin{array}{c}\text { Mean } \\
\text { Delivery Time } \\
\text { (hrs) }\end{array}$ & $\begin{array}{c}\text { No. of } \\
\text { Cases With } \\
\text { Complications }\end{array}$ \\
\cline { 1 - 2 } & & $40 \cdot 2$ & $13 \cdot 7$ & 2 \\
1 & $41 \cdot 0$ & & $15 \cdot 9$ & 2 \\
2 & $41 \cdot 5$ & & $24 \cdot 7$ & $! 2$ \\
\hline
\end{tabular}

TABLE 4

\begin{tabular}{|c|c|c|c|c|c|}
\hline & Unknown & Normal & Doubtful & Moderate & Pronounced \\
\hline Variable & $\mathbf{x}$ & 0 & 1 & 2 & 3 \\
\hline
\end{tabular}

TABLE 5

THE VARIABLES THAT WERE RECORDED

\begin{tabular}{|c|c|c|}
\hline History & Physical & camination \\
\hline $\begin{array}{l}\text { Generial } \\
\text { 1. Convulsions } \\
\text { 2. Vision } \\
\text { 3. Hearing } \\
\text { 4. Develooment } \\
\text { 5. Sat without } \\
\text { susport } \\
\text { 6. Walked } \\
\text { 7. Talked simple } \\
\text { sentences } \\
\text { 8. Ceased bed } \\
\text { wetting } \\
\text { 9. Frequent } \\
\text { infections } \\
\text { 10. Hospitalized } \\
\text { During First Month } \\
\text { 11. Lazy infant } \\
\text { 12. Bad surkler } \\
\text { 13. Jaundiced } \\
\text { 14. Cyanosed }\end{array}$ & $\begin{array}{l}\text { General } \\
\text { 15. Height } \\
\text { 16. Sitting height } \\
\text { 17. Weight } \\
\text { 18. Head circum- } \\
\text { ference } \\
\text { 19. Fontanelle } \\
\text { 20. Heart } \\
\text { 21. Electrocardio- } \\
\text { gram } \\
\text { 22. Hearing } \\
\text { (reaction to } \\
\text { noise) } \\
\text { 23. Nystagmus } \\
\text { 24. Strabismus } \\
\text { 25. Diadokokinesis }\end{array}$ & $\begin{array}{l}\text { Reflexes } \\
\text { 26. Pupillar } \\
\text { 27. Patellar } \\
\text { 28. Achilles } \\
\text { 29. Bice s-triceps } \\
\text { 30. A bdominal } \\
\text { 31. Plantar } \\
\text { Veuromuscular } \\
\text { 32. Cranial nerves } \\
\text { 33. Muscular atrophy } \\
\text { 34. Abnormal } \\
\text { 35. Chorecular tone } \\
\text { 36. Tremor } \\
\text { 37. Spasticity } \\
\text { 38. Flaccidity } \\
\text { 39. Reduced muscu- } \\
\text { 40. Romborger } \\
\text { 41. Alertness sign } \\
\text { 42. Sococh } \\
\text { 43. Vision } \\
\text { 44. Eye fundi }\end{array}$ \\
\hline
\end{tabular}

as the difference between the observed value and the predicted.

\section{Results}

Of the 46 variables studied it was found that in the following all or almost all the children were normal; i.e. numbers $1-4,11-14,16,18-25,32,33$, $35-37,40,42-44$.

The mean scores for the remaining variables including the intelligence tests are given in Table 6. The mean scores were obtained by summating and averaging the scores obtained by all children in each maturity stage. When information was not obtained, i.e. the protocol was marked 'unknown', the number of cases actually scored is given.

It will be seen that the most pronounced difference in the variables referring to case history is increased frequency of infections.

The most important finding in the general physical examination is the reduced weight of infants in Stage 2. Table 6 shows that although the mean weights in all the three stages of dysmaturity are 
TABLE 6

MEAN SCORE FOR ALL VARIABLES SHOWING MORE THAN OCCASIONAL DEVIATION FROM NORMAL

\begin{tabular}{|c|c|c|c|c|c|c|c|c|c|c|c|c|}
\hline \multirow[t]{2}{*}{ Variable } & \multicolumn{2}{|c|}{$\begin{array}{c}5 \\
\text { Delayed } \\
\text { Sitting }\end{array}$} & \multicolumn{2}{|c|}{$\begin{array}{c}6 \\
\text { Delayed } \\
\text { Walking }\end{array}$} & \multicolumn{2}{|c|}{$\begin{array}{c}7 \\
\text { Delayed } \\
\text { Talking }\end{array}$} & \multicolumn{2}{|c|}{$\begin{array}{c}8 \\
\text { Persistent } \\
\text { Bed Wetting }\end{array}$} & \multirow[t]{2}{*}{$\stackrel{9}{\%}$} & \multirow[t]{2}{*}{$\begin{array}{c}10 \\
\text { Repeated } \\
\text { Infections }\end{array}$} & \multirow[t]{2}{*}{$\begin{array}{c}15 \\
\text { Height* } \\
\text { (cm.) }\end{array}$} & \multirow[t]{2}{*}{$\begin{array}{c}16 \\
\text { Weight } \\
\text { (kg.) }\end{array}$} \\
\hline & No. & & No. & & No. & & No. & & & & & \\
\hline $\begin{aligned} & \text { Stage } 0 \\
& 1 \\
& 2\end{aligned}$ & $\begin{array}{l}13 \\
24 \\
27\end{array}$ & $\begin{array}{l}1 \cdot 15 \\
1 \cdot 22 \\
1 \cdot 22\end{array}$ & $\begin{array}{l}15 \\
24 \\
30\end{array}$ & $\begin{array}{l}0 \cdot 20 \\
0 \cdot 25 \\
0 \cdot 20\end{array}$ & $\begin{array}{l}19 \\
25 \\
33\end{array}$ & $\begin{array}{l}0.79 \\
0.80 \\
0.90\end{array}$ & $\begin{array}{l}17 \\
27 \\
33\end{array}$ & $\begin{array}{l}0 \cdot 84 \\
0 \cdot 22 \\
0 \cdot 88\end{array}$ & $\begin{array}{l}37 \\
30 \\
41\end{array}$ & $\begin{array}{l}0.42 \\
0.56 \\
0.79\end{array}$ & $\begin{array}{l}-3 \cdot 39 \\
-1 \cdot 11 \\
-1 \cdot 94\end{array}$ & $\begin{array}{l}-2 \cdot 11 \\
-0 \cdot 71 \\
-0 \cdot 42\end{array}$ \\
\hline Variable & \multicolumn{2}{|c|}{$\begin{array}{c}26-31 \\
\text { Total Score } \\
\text { For All } \\
\text { Reflexes }\end{array}$} & \multicolumn{2}{|c|}{$\begin{array}{c}34 \\
\text { Abnormal } \\
\text { Muscular } \\
\text { Tone }\end{array}$} & \multicolumn{2}{|c|}{$\begin{array}{l}38 \\
\text { Flaccidity }\end{array}$} & \multicolumn{2}{|c|}{$\begin{array}{c}39 \\
\text { Muscular } \\
\text { Power }\end{array}$} & $\begin{array}{c}41 \\
\text { Alertness }\end{array}$ & $\begin{array}{c}45 \\
\text { Terman- } \\
\text { Merill }\end{array}$ & $\stackrel{46}{\text { Goodenough }}$ & \\
\hline $\begin{array}{rr}\text { Stage } & 0 \\
1 \\
2\end{array}$ & \multicolumn{2}{|c|}{$\begin{array}{l}0.58 \\
0.89 \\
0.85\end{array}$} & \multicolumn{2}{|c|}{$\begin{array}{l}0 \cdot 47 \\
0 \cdot 37 \\
0 \cdot 53\end{array}$} & \multicolumn{2}{|c|}{$\begin{array}{l}0.79 \\
0.52 \\
0.68\end{array}$} & \multicolumn{2}{|c|}{$\begin{array}{l}0 \cdot 11 \\
0 \cdot 15 \\
0 \cdot 24\end{array}$} & $\begin{array}{c}0 \cdot 15 \\
0 \cdot 26 \\
0 \cdot 47\end{array}$ & $\begin{array}{l}110 \cdot 0 \\
109 \cdot 5 \\
104 \cdot 1\end{array}$ & $\begin{array}{l}113 \cdot 6 \\
108 \cdot 9 \\
105 \cdot 3\end{array}$ & \\
\hline
\end{tabular}

- Height is given as mean deviation in $\mathrm{cm}$. from normal standard.

- Weight is given as mean deviation in $\mathbf{k g}$. from normal standard.

above the predicted value Stage 2 weights are less than Stage 0.

It might be thought that the lower weight of Stage 2 was due to the increased frequency of infection. However, no such correlation could be demonstrated.

From the Children's Health Centre weight charts were obtained for 24 of the Stage 2, 20 of the Stage 1 and 16 of the Stage 0 infants. The mean birth weight of Stage 0 was $3.7 \mathrm{~kg}$., of Stage $1,3.4 \mathrm{~kg}$., and of Stage $2,3.5 \mathrm{~kg}$. An analysis of these weights showed that Stage 2 increased more in weight during the first six months of life, but this difference was not statistically significant. Between 1 and 2 years the Stage 2 infants increased less than the Stage 0 infants (an almost significant difference, $t=2.3 ; p<0.05)$. The reduced weight of the Stage 2 infants is thus due to the initially lower birth weight and to the slower weight increase between 1 and 2 years.

In only one of all the variables studied in which any appreciable scoring was present, i.e. in variable 41 (flaccidity) was Stage 0 inferior to Stage 2.

The intelligence tests both showed lower values for Stage 2 than for Stage 0, and Stage 1 held an intermediate position.

\section{Statistical Analyses}

The low scoring and the rather small differences generally observed explains the absence of statistical significance in any of the individual variables that were scored. A comparison between the individual means was only done in those which primarily were obtained in figures, i.e. height, weight and the intelligence test.

Comparison of the mean values between Stage 0 and Stage 2 showed that (1) for height, the difference was not significant $(t=1 \cdot 0 ; p<0 \cdot 10)$; (2) for weight, the difference was almost significant $(t=2 \cdot 1$; p < 0.05); (3) for Terman-Merill, almost significant $(\mathrm{t}=1.8 ; \mathrm{p}<0.05)$; and (4) for Goodenough, significant $(t=2 \cdot 5 ; p<0.01)$.

In the variables listed in Table 6 , Stage 0 is equal to or better than Stage 2 in 14 of them. The probability that this has occurred fortuitously is $\frac{5}{2^{14}}=\frac{1}{3276} ; \mathrm{p}<0.001$. In other words, Stage 2 is statistically highly significantly inferior to Stage 0 .

So far in the statistical analyses no account has been taken of Stage 1. This can be done by an extension of the sequence analyses used above. The probability that the values will come in the sequence $0,1,2$, with the least favourable value in 2 is $1 / 6$. The probability for the sequence $1,0,2$ or 'better' is $2 / 6$ and for the sequence $0,2,1$, or 'better' is $3 / 6$.

The actual sequence of the 15 variables, which gave more than occasional abnormal findings, may be observed in Table 6 . A calculation of the probability for this sequence having regard to all the 15 variables gives the figure $10^{-5}$. Thus, by taking Stage 1 into account also, the statistical significance is greatly increased.

If only two groups are compared, i.e. Stage $\mathbf{0}$ and Stage 2, a favourable sequence 0,2 , in 12 variables is needed for a highly significant difference. When an intermediate group gives the sequence $0,1,2$, only four variables are needed for a $\mathrm{p}<0.001$ significance.

Those variables that give the sequence $0,1,2$, will be the most useful in distinguishing dysmature infants from infants normal at birth. These variables are delayed talking, repeated infections, relatively lower weight, decreased muscular tone, 
decreased alertness and inferior score for TermanMerill and Goodenough tests.

In Table 7 these seven variables have been scored according to the previously mentioned $0,1,2,3$ scoring system and the mean score and the range for each stage of dysmaturity is shown in order to try to illustrate how much the stages of dysmaturity differ.

TABLE 7

MEAN TOTAL SCORE FOR SEVEN MOST IMPORTANT VARIABLES FOR DISTINGUISHING DYSMATURE INFANTS FROM CONTROLS

$\begin{array}{rr}\text { Stage } & 4.6 \text { S.D. } 3.6 \text { (range 0-13) } \\ 1 & 5.3 \text { S.D. } 5.4 \text { (range 0-19) } \\ 2 & 7.5 \text { S.D. } 4.6 \text { (range 2-18) }\end{array}$

The differences between Stage 0 and Stage 2 are statistically significant.

In 23 of $34(60 \%)$ of Stage 2 infants the score is higher than the mean score for Stage 0. Corresponding figures are 12 out of $26(46 \%)$ of Stage 1 and six out of $18(33 \%)$ in Stage 0 . The mean score +2 S.D. in Stage 0 is 11 . Outside this there is one infant $(5 \%)$ in Stage 0 , three $(12 \%)$ in Stage 1 and six $(18 \%)$ in Stage 2.

A review of the delivery records revealed no correlation between the abnormalities listed in Table 4 and a high score.

\section{Discussion}

In the study of dysmaturity by Sjöstedt et al. (1958) the age of the mothers was given in five-year groups. This evidently masked a higher age of the mothers of the dysmature infants as such a difference has now been found between the unbiased selection of Stage 1 and Stage 2.

Hepner and Bowen (1960) published a follow-up study of infants who at birth had deficient placentas. These infants were all small in weight at birth and remained small in weight and height during the time of follow-up, i.e. One year. The present study has shown that the weight deficiency is present even at 4 to 5 years of age. However, during the first six months these infants increase more rapidly in weight than normal ones. Special attention should therefore be given to the nourishment of the dysmature infants who might need supplementary iron, vitamins and proteins over and above the requirements of normal infants.
Bowen and Hepner (1959) described an increased frequency of mental retardation in their group of infants. We have, in the present follow-up, found no such case and no case of cerebral palsy. It is probable that Bowen and Hepner's cases were Stage 3 dysmaturity, whereas most of ours were Stage 2.

There is no doubt that, taken as a whole group, Stage 2 is inferior to the control infants. However, many of the Stage 2 infants are as good as the normals in every respect.

Dysmaturity is not only a diagnosis of academic interest in the perinatal period, it is a diagnosis that has importance also for the future development of the infant. At present it may be summarized as being a disadvantage, although not a serious one.

\section{Summary}

Thirty-four or $75 \%$ of the infants born dysmature Stage 2 or 3 in 1956 and 1957 were examined in a follow-up study and matched with 19 controls selected at random. Also 26 cases dysmaturity Stage 1 chosen at random were studied for comparison.

A total of 46 qualities in their case history and their physical examination, including two psychological tests were studied. All the results were scored by the observing clinician at the time of the examination.

In 15 of these total 46 variables more than occasional deviations from the normal were observed. In 14 of them, the Stage 2 infants were inferior to Stage 0 infants and often Stage 1 held an intermediate position. Statistically the differences were most obvious in those variables where the examination gave a direct figure, i.e. weight and the psychological tests. Pooling the results from all tests the differences were statistically highly significant.

We are indebted to Assistant Jörgen Jacobsen from the Department of Statistics for statistical advice.

\section{ReFERENCES}

Bowen. M. and He pner, R. (1959). Placental insufficiency and grown h. A.M.A.J. Dis. Child. 98. 567.

Hepner, $R$. and Bowen. M. (1960). The placenta and the fe:us. J. Amer. med. Ass., 172.427

Karlberg. P. and Perman. A. (1959). Some physical measurements (weight, length, head circumference and chest circumference) in healthy Swedish children in the first two years of life. Acto paediat. (Unpsala), Suopl. 117. 128.

Sjöstedt. S.. Engleson, G. and Rooth, G. (1953). Dysmaturity Arch. Dis. Childh., 33, 123. 